\title{
Was Iraq War a "Just War" or Just a War? An Analysis from the Perspectives of Just War Theory
}

\author{
Ting Chun Ngai \\ Department of Public Policy, City University of Hong Kong, Hong Kong, China \\ Email: andyngai0104@gmail.com
}

How to cite this paper: Ngai, T. C. (2019). Was Iraq War a "Just War" or Just a War? An Analysis from the Perspectives of Just War Theory. Open Journal of Political Science, 9, 373-382. https://doi.org/10.4236/ojps.2019.92020

Received: March 15, 2019

Accepted: April 12, 2019

Published: April 15, 2019

Copyright ( 2019 by author(s) and Scientific Research Publishing Inc. This work is licensed under the Creative Commons Attribution International License (CC BY 4.0).

http://creativecommons.org/licenses/by/4.0/

\begin{abstract}
Whether or not the Iraq war should be regarded as a "Just War" or just a war has been sparked a lot of academic and public debates since 2003. Within the academic world of war politics, there are heterogeneous perspectives, such as Pacifism and Realism etc. This paper chose to analyse the issue by the employment of the Just War Theory. It generated the various arguments of the thinkers from the school of Just War philosophy and adopted a case study methodology to examine the nature of Iraq war. After a comprehensive analysis, it can be concluded that the Iraq war is an unjust war from the perspective of just war theory.
\end{abstract}

\section{Keywords}

Just War Theory, War Politics, Iraq War

\section{Introduction}

The US invaded Iraq in 2003 as the former claimed that the latter possess Weapons of Mass Destruction (WMDs) and liberalizes Iraqis from the tyranny regime of Saddam Hussein (Mockaitis, 2012). Since then, controversy appears within academia on whether Iraq War in 2003 should be regarded as "A Just War" or "Just a War" (Lecamwasam, 2013). Some scholars embraced the idea of "Pacifism" and argued Iraq war or regardless any kind of warfare is characteristically unjust as monstrous killing is erroneous (Rae, 2009; Cady, 2010; Burkholder \& Cramer, 2012). In contrast, other scholars, like Amstutz (2005), Williams (2012) and Welch (2013) drew the inference that Iraq war can be justified as it served the state interest by utilizing the idea of political realism. Therefore, the following paper adopted Just war theory (jus bellum iustum) to analysis 
the nature of Iraq War in 2003 by comprehensively examining the criteria proposed by the corresponding scholars.

\section{Just War Theory as Analytical Framework}

Traditional Just war theory incorporates two major dimensions, namely the justice to war (jus ad bellum) and justice in war (jus in bello).

\section{Justice to war (jus ad bellum)}

Several facets are included in the idea of the right to go to war. Firstly, the declaring of war must be the last resort for resolving political conflict (Carpenter, 2005; Mouch, 2006; Lango, 2014). Every possible peaceful option must be depleted before subject to military resolution. Walzer (2015) accentuates it is the demonstration of the primacy of peace over war in just war thinking. Besides, the declaring of war should possess just cause and right intention. A just cause means a country can only launch a war for justified reasons, for instance, the war that claims for maintaining peace or self-defence, which usually involved some righteous ideals (Elshtain, 1992; Fiala, 2008). While the right intention would a more specific and the only purpose of just cause, which a military action must not achieve the just intention that it claimed, but actually or inwardly working on another purposes (Fabre, 2008; Parry, 2015). Moreover, war must be initiated and waged by a legitimate authority under just war theory. Campbell (2007) and Parry (2015) argue the decision of declaring war must go through a prudent process of evaluation of cost and benefit and gain majority support from the concerning parties, also the state or the global agencies must take obligations for their action. Additionally, a high probability of success must be ensured before the war. As war will prompt an overwhelming of damage on human lives, economic loss, as well as social destruction to the parties involved, so it is unjustifiable to initiate war without any reasonable prospect of success (Hudson, 2009; Brown, 2017). The last dimension within jus ad bellum is the proportionality between good and sinister outcome. An authority must gauge and evaluate the overall consequences of the war in the pre-war period, which not only consider its own benefits and losses, yet the impacts towards the enemies and innocent third parties must also take into account, and the action of going to war can be justified only if the positive outcome is supremely outperforming the negative sides (Solis, 2010; Chatterjee, 2011; Webel \& Barash, 2013).

\section{Justice in war (jus in bello)}

Another dimension that proposes by the just war theorists is the right conduct of warfare. When there is a warfare, a few standards that commanders and soldiers, who perform war orders, must be strictly followed to forestall any sorts of war crimes. The first rule is the discrimination between military targets and the innocents (Baer, 2014). The soldiers involved in the war must not target unarmed civilians as an object of assault, and their military actions must wound civilians as less as possible, while the other is the proportionality of weapons usage. The army must confine the power of the weapons used to the level of "ap- 
propriate violence" according to the operation goals in order to avoid excessive and superfluous damage (Newton \& May, 2014). Hensel (2013) also suggests the code of humanity. It underlined the importance of the basic human rights of the civilians, the refugees, the surrenders as well as the detainees of war must not be violated.

Modern theorists of just war deemed the traditional theory is not comprehensive enough as some criteria of justice must be embodied after the military battle, hence, an idea of justice after the war (jus post bellum) is proposed.

\section{Justice after war (jus post bellum)}

Scholars, like Gentry \& Eckert (2014), suggested that there must be just cause for termination. The war must be terminated immediately once that the goals of the just war has been achieved. Also, the justice of crime that people who conduct war crime must be subject to fair and just trial (Lasiello, 2004; Orend, 2007). Moreover, the responsibilities of reconstructing of post-war society. Bass (2004) mentions that the justice of post-war rule is embodied on the triumphant party, which they must bear the onus to aid the losing sides for rebuilding their society and re-establish social and political order.

\section{Iraq War in 2003: A Review}

The whole story traced back to the year 1990, the time that the Iraqi army invaded and occupied Kuwait on the ground of disputes on territory and oil exportation. Iraq not only claimed Kuwait belongs to Iraqi territory, but also it violated the OPEC quotas for oil production (Ohaegbulam, 2007). This triggered the Gulf War afterward and Iraq subjected to United Nations sanctions and arms inspections of mass destructive weapons.

In 2001, the astonishing 9/11 happened. The Bush's administration accused Saddam Hussein, the Iraqi president has a close connection with Osama bin Laden, a symbolic figure of global terrorism. Bush even claimed Iraq, along with North Korea and Iran, as a member of the "axis of evil" (The Washington Post, 2002). The Iraqi issue soon become the agenda in the UN Security Council, which Bush warned Iraq that there would be a military consequences if it failed to fulfill the requirements of disarmament (The New York Times, 2002), and the UK government publishes a dossier on the threat posed by Iraq (The British Government, 2002). A year after the US and UK administration filed draft for military action as they deemed Iraq missed the "final opportunity" of disarmament, but the motion voted by France and Russia.

Finally, the US and UK abandon their attempt to secure UN resolution authorizing force and solely seek the consent from their legislative branch. By announcing Iraq possesses WMDs, supports terrorism and disregards the UN resolutions for global peace, the US, UK as well as their allies invaded Iraq in 2003.

\section{Case Study: Was Iraq War a "Just War"?}

Three significant dimensions of just war theory and their features were identi- 
fied above and used to analyse the US in the intrusion to Iraq in 2003. After a comprehensive scrutinizing, it is certainly to conclude that it is not regarded as an example of just war from the perspective of just war theory.

The US intrusion fails to fulfil the justice to war. Before the outbreak of Iraq war, the US ally accused Iraq possess WMDs which prompted an instant threat to the global safety and it is extremely urgent to invade Iraq for demilitarization. However, the Iraq authority has claimed they were being framed and permitted the United Nation weapons inspection team to investigate inside their territory. Finally, the UN report mentioned Iraq had cooperated "immediately, unconditionally and actively" and had not found any WMDs (Security Council, 2003). This indicated how the just war thinking of "Last resort" has been violated as Iraq regime obviously does not impose any instant threat to the globe, but the US ally insisted to aggress Iraq. Moreover, the US ally also goes against the idea of "Just cause and right intention". Apparently, the official goals announced by the US ally are to destroy WMDs in Iraq and overthrow Saddam regime. It seems like their military intrusion is based on the righteous purposes for the Iraqi and even the globe, but many alternative purposes were not revealed to the world. Scholars, like Copson (2003) Askari (2007), think the implicit intrigue is the establish US political influence in Middle-East. Besides, a former US official revealed that the ultimate objective of Iraq war is to plunder economic resource, which is oil, and he describes the success of topple down Saddam administration is just a fortunate outcome (Fox News, 2007). Hence, it is obvious to observe the war is not as simple as a fight for "Just cause and right intention", but indeed for national interest. The significant factor that embodied the 2003 invasion of Iraq is the proportionality between good and evil outcome. Before the intrusion, the US estimated that the war will only last for few months and only around a hundred of lives may sacrifice, as well as the war expenditure will only cost one percent of the gross domestic product (Kurtzleben, 2011), while these sorts of the cost will emancipate the Iraqi from tyranny regime and maintain global peace, which is worth to go for. However, everything was miscalculated. The war actual lasts long for almost ten years as it started in 2003 and ended in the November of 2011, the time that entire withdrawal of the US troops (Steed, 2019). Even though the US government claimed triumph two months after the invasion, but vast sporadic military conflicts happened and around four thousand US soldiers were killed until the withdrawal. In terms of economic loss, more than $\$ 2$ trillion dollars was spent, which extraordinary higher than the pre-war $\$ 300$ billion war appropriation (Beehner, 2006), for both war and post-war expense (Trotta, 2013). Despite the US and its ally has paid a great cost for this war, the Iraq society suffers heavier. Ironically, the US troops have not found any WMDs at all and people at there no longer live under tyranny rule, but rather suffer in long going social and political unsteadiness. In fact, there are only two criteria that the war can be justified, namely the "legitimate authority" and "reasonable prospect of success". The military action launched by the US must be gained the endorsement from the Congress and the majority of the population chose to be- 
lieve the US government and bolster their actions (Saad, 2002). Moreover, the US government take up the responsibility for post-war reconstruction in Iraq, which showed the US ally achieved the standard of "legitimate authority". While there will be no controversy of the latter criteria. The troops that aggress Iraq are mostly formed by the US and the UK, which are the most advanced forces in the world and their military capacity is, no doubt, superior to Iraq. Therefore, it certainly concludes the 2003 invasion of Iraq, to a tremendous extent, do not fulfil the idea of justice to war.

Adding to the contention that Iraq war should not regard as a just war is the justice in war is not epitomized. Many newspapers revealed that the US ally also tortures the prisoners of war. The most prominent example is the Abu Ghraib prison. Prisoners inside subjected to various kind of torments, for instance, some of them confronted walloping by the US privates, while some female prisoners experienced sexual abuses, such as forced to be taken nude photographs (Meyer, 2004). Hence, how can these inhume conduct of US ally can justify as a just move? Also, the US ally has not followed the rule of proportionality of force used and their goals. Immoderate violence was used amidst the war, for example, a rebel hid on the roof of a building and the US troops blow up the entire building (Goldman \& Martinez, 2010). What is more inadmissible is even though the US has an overwhelming advantage on military capacity than Iraq, it still chose to use chemical weapons for invasion. Depleted uranium (DU) weapons, which are regarded as small nuclear bombs, were fired during the war and people suffer from sequelae of radiation (Edwards, 2014). It is not justified that the US undue use of violence. Discrimination between the target and innocent has also been overlooked by the US ally. The secret documents unveiled by Wikileaks suggest US army had not taken innocent life seriously. It is not uncommon to see that a monstrous number of manslaughter occurred during the war. For example, a US patrol got an intelligence that there are suspected "Anti-Iraq Force" members appeared in Eastern Baghdad and they not only did not confirm the reality of the source and they simply shoot anyone when they arrived, and ultimately fourteen civilians were killed (Pugliese, 2013). Julian Assange, the founder of WikiLeaks, contended the number of death in Iraq war is five times more than that in Afghanistan war and label it is a "bloodbath" (The Sydney Morning Herald, 2010). Hence, there is not any justice in war can be observed.

Furthermore, no post-war justice can be seen after the 2003 invasion of Iraq. The Former Iraqi President Saddam Hussein was captured by the US ally two months after the outbreak of war. According to the theory of just cause for termination, the original objective has achieved and there must not have any warfare occurred; however, this is not the story of Iraq war. After the collapse of Saddam regime, the US proactively props up the pro-American regime and this sparked the dissatisfactions among domestic factions of political organizations. In order to ensure the stability of pro-American administration and protect the long-term national interests, the US decided to fight against the Iraqi Guerrillas, 
which is the major reason why the Iraq war has been expanded to ten-years long (Hayden, 2007). Besides, the justice of war crime has not demonstrated in the post-war period. As mentioned above, the situations of the severe conduct of infringement of human rights did by the US troops, yet only one of them has been subjected to trial subsequently. Ironically, the people who accusation of a felony by the US government is Chelsea Elizabeth Manning, a courageous senior soldier who discloses the atrocities of US ally in the battlefield to Wiki Leaks (Deiseroth, 2014). Thus, how post-war justice can be achieved if the US government chose to tolerate the fiendish behaviours of its soldiers? Whether the US has consummated its onus to re-establish the political and social order in Iraq is controversial. No doubt, numerous actualities showed the Iraqi economy has rebuilt and grown in recent years, and stable democratic elections have held several years. Scholars Neimann, Jaco \& Epstein (2003) do not regard it as an embody of after war justice as most of the rebuild projects are operated by the US enterprises, also, the US government gain a lot of revenue though the oil export from Iraq and manipulate the election for pro-US Shia regime, which simply serving the national interest rather than genuinely devote on Iraq reconstructions. Additionally, the rise of The Islamic State (IS) and amplify regional unrest also have something do with the 2003 invasion of Iraq.

\section{Conclusion}

The whole war is started after the slander towards Iraq indicated by the US and its ally. The UN has claimed it is not valid after investigation, but they insist attack Iraq nevertheless. Moreover, numerous misconducts among soldiers emerged and excessive violence and weapons were employed. Besides, the US government overlooked the legal onus of the privates who conduct war crime and simply expand their own gain after war. Thus, most of the criteria of just war theory were not typified no matter in the period of pre-war, in the midst of warfare as well as post-war. The war embodied no justice but brought tremendous loss for both parties. Apart from the US economic loss that pinpointed above, The U.S. Department of Defense (2019) recorded total 4,423 of deaths and 31,975 wounded. A more catastrophic impact can be observed in Iraq. In terms of casualties, at least 134,000 civilians have been killed since 2003 (Crawford, 2013). Even it is approximately 15 year after the U.S.-led invasion; Iraq has yet to fully rebuild its country (Calamur, 2018). Indubitably, it can be concluded that the Iraq war in 2003 is an unjust war from the perspective of just war theory.

\section{Conflicts of Interest}

The author declares no conflicts of interest regarding the publication of this paper.

\section{References}

Amstutz, M. R. (2005). International Ethics: Concepts, Theories, and Cases in Global 
Politics.

https://books.google.com.hk/books?id=qTYko_PygLYC\&dq=Iraq+war+political+realis $\underline{\mathrm{m}+\text { protect }+ \text { national+interest } \& \mathrm{hl}=\mathrm{zh}-\mathrm{TW} \& \text { source }=\mathrm{gbs} \_ \text {navlinks_s }}$

Askari, H. (2007). Middle East Oil Exporters: What Happened to Economic Development?

https://books.google.com.hk/books?id=aWBA7rcvhrQC\&dq=iraq+war+US+control+ middle+east\&hl=zh-TW\&source=gbs_navlinks_s

Baer, H. D. (2014). Recovering Christian Realism: Just War Theory as a Political Ethic. https://books.google.fr/books?id=lK-DBQAAQBAJ\&pg=PA75\&dq=The+first+rule+is +the+discrimination+between+military+targets+and+the+innocents+just+war \&hl=en \&sa $=X \& v e d=0$ ahUKEwiSos7dobHhAhUQyYUKHVqyAfEQ6AEIKjAA\#v=onepage\&q $=$ The $\% 20$ first $\% 20$ rule $\% 20$ is $\% 20$ the $\% 20$ discrimination $\% 20$ between $\% 20$ military $\% 20$ targ ets\%20and\%20the\%20innocents\%20just\%20war\&f=false

Bass, G. J. (2004). Jus Post Bellum. Philosophy and Public Affairs, 32, 384-412.

https://doi.org/10.1111/j.1088-4963.2004.00019.x

https://philpapers.org/rec/BASJPB-2

Beehner, L. (2006). The Cost of the Iraq War. Council on Foreign Relations Newsletter. https://www.cfr.org/backgrounder/cost-iraq-war

Brown, D. (2017). The Just War Tradition: Applying Old Ethics to New Problems. https://books.google.com.hk/books?id=Py4rDwAAQBAJ\&dq=probability+of + success+ jus+ad+bellum \&hl=zh-TW\&source=gbs_navlinks_s

Burkholder, J. S., \& Cramer, D. C. (2012). The Activist Impulse: Essays on the Intersection of Evangelicalism and Anabaptism.

https://books.google.com.hk/books?id=wIFMAwAAQBAJ\&dq=pacifism+Iraq+War+u $\underline{\text { njust }+ \text { war\&hl=zh-TW\&source }=\text { gbs_navlinks_s }}$

Cady, D. (2010). From Warism to Pacifism: A Moral Continuum. https://books.google.com.hk/books?id=lRVFs85rPuAC\&dq=pacifism+Iraq+War+unju $\underline{\text { st }+ \text { war\&hl=zh-TW\&source }=\text { gbs_navlinks_s }}$

Calamur, K. (2018). Oil Was Supposed to Rebuild Iraq. The Atlantic. https://www.theatlantic.com/international/archive/2018/03/iraq-oil/555827

Campbell, L. B. (2007). Just War, Legitimate Authority and Non-State Actors. https://mospace.umsystem.edu/xmlui/bitstream/handle/10355/10897/CampbellJusWar Leg.pdf? sequence $=1$ \&isAllowed $=\mathrm{y}$

Carpenter, A. L. (2005). From Missionary to Mercenary: How the Church Went from Pacifism to Militancy and Why It Should Return.

https://books.google.com.hk/books?id=DCxPwW4QZv8C\&dq=just+war+theory+last+ resort\&hl=zh-TW\&source $=$ gbs_navlinks_s

Chatterjee, D. K. (2011). Encyclopedia of Global Justice: AI. https://books.google.com.hk/books?id=2swUg4ZKTgsC\&dq=Proportionality+of+good +bad+outcome+jus+ad+bellum+just+war+theory\&hl=zh-TW\&source=gbs_navlinks_s

Copson, R. W. (2003). The Iraq War: Background and Issues. https://books.google.com.hk/books?id=WS78N_t9AIUC\&dq=iraq+war+increase+US+ influence + in + Middle-East\&hl=zh-TW\&source=gbs_navlinks_s

Crawford, N. C. (2013). Civilian Death and Injury in the Iraq War, 2003-2013. https://watson.brown.edu/costsofwar/files/cow/imce/papers/2013/Civilian\%20Death\% 20and\%20Injury\%20in\%20the\%20Iraq\%20War\%2C\%202003-2013.pdf

Deiseroth, F. (2014). Whistleblower in der Sicherheitspolitik-Whistleblowers in Security Politics: Preisverleihung-Awards 2011/2013 (Chelsea E. Manning; Edward J. Snowden). 
https://books.google.fr/books?id=WkFqBAAAQBAJ\&pg=PA34\&dq=Chelsea+Manning+Wi kileaks+iraq+war+Deiseroth, $+2014 \& \mathrm{kl}=$ en\&sa=X\&ved=0ahUKEwja65e3oLHhAhVBLBoK HRORBqUQ6AEIKjAA\#v=onepage\&q=Chelsea\%20Manning\%20Wikileaks\%20iraq\%20wa r\%20Deiseroth\%2C\%202014\&f=false

Edwards, R. (2014). US Fired Depleted Uranium at Civilian Areas in 2003 Iraq War, Report Finds. Guardian News.

https://www.theguardian.com/world/2014/jun/19/us-depleted-uranium-weapons-civili an-areas-iraq

Elshtain, J. B. (1992). Just War Theory.

https://books.google.com.hk/books?id=y4gUCgAAQBAJ\&dq=just+war+theory+just+c ause\&hl=zh-TW\&source $=$ gbs_navlinks_s

Fabre, C. (2008). Cosmopolitanism, Just War Theory and Legitimate Authority. International Affairs (Royal Institute of International Affairs 1944), 84, 963-976.

https://doi.org/10.1111/j.1468-2346.2008.00749.x

http://www.jstor.org/stable/25144931

Fiala, A. G. (2008). The Just War Myth: The Moral Illusions of War. https://books.google.com.hk/books?id=FEaW00i8ErMC\&dq=just+war+theory+just+c ause\&hl=zh-TW\&source=gbs_navlinks_s

Fox News (2007). Alan Greenspan Seeks to Clarify Controversial Iraq War Comments. Fox News.

http://www.foxnews.com/story/2007/09/17/alan-greenspan-seeks-to-clarify-controvers ial-iraq-war-comments.html

Gentry, C. E., \& Eckert, A. E. (2014). The Future of Just War: New Critical Essays. https://books.google.com.hk/books?id=jAbaCgAAQBAJ\&dq=just+war+theory+jus+po

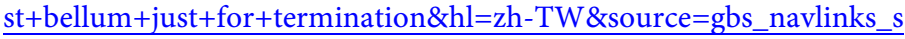

Goldman, R., \& Martinez, L. (2010). WikiLeaks: At Least 109,000 Killed During Iraq War. ABC News.

http://abcnews.go.com/Politics/michelle-wolf-roasting-sarah-huckabee-sanders-ignites -backlash/story?id=54812012

Hayden, T. (2007). Ending the War in Iraq. https://books.google.com.hk/books?id=ODQ88K1rdlUC\&dq=The+us+Iraqi+Guerrilla s\&hl=zh-TW\&source $=$ gbs_navlinks_s

Hensel, H. M. (2013). The Legitimate Use of Military Force: The Just War Tradition and the Customary Law of Armed Conflict.

https://books.google.com.hk/books?id=rAIOjCapxqMC\&dq=just+war+jus+in+bello+h $\underline{\text { umanity\&hl=zh-TW\&source }=\text { gbs_navlinks_s }}$

Hudson, K. A. (2009). Justice, Intervention, and Force in International Relations: Reassessing Just War Theory in the 21st Century.

https://books.google.com.hk/books?id=HVN5AgAAQBAJ\&dq=probability+of +success + jus + ad+bellum\&hl=zh-TW\&source $=$ gbs_navlinks_s

Kurtzleben, D. (2011). What Did the Iraq War Cost? More than You Think. U.S. News. https://www.usnews.com/news/articles/2011/12/15/what-did-the-iraq-war-cost-more-t han-you-think

Lasiello, L. V. (2004). Jus Post Bellum. U.S. Naval War College Digital Commons, 57, 33-52.

http://digital-commons.usnwc.edu/cgi/viewcontent.cgi? article=2151\&context=nwc-rev iew

Lango, J. W. (2014). Ethics of Armed Conflict: A Cosmopolitan Just War Theory. https://books.google.com.hk/books?id=AiirBgAAQBAJ\&dq=just+war+theory+last+res 
$\underline{\text { ort+Michael+Walzer\&hl=zh-TW\&source }=\text { gbs_navlinks_s }}$

Lecamwasam, N. (2013). Iraq Invasion: A “Just War” or Just a War? http://www.e-ir.info/2013/06/06/iraq-invasion-a-just-war-or-just-a-war

Meyer, D. (2004). Rush: MPs Just Blowing off Steam. CBS News. https://www.cbsnews.com/news/rush-mps-just-blowing-off-steam

Mockaitis, T. R. (2012). The Iraq War: A Documentary and Reference Guide. https://books.google.com.hk/books?id=DWxsVtu1BG4C\&dq=Iraq+Invasion\&hl=zh-T W\&source $=$ gbs_navlinks_s

Mouch, P. M. (2006). Last Resort and Just War. JSTOR Public Affairs Quarterly, 20, 235-246. https://www.jstor.org/stable/40441440?seq=1\#page_scan_tab_contents

Neimann, J. C., Jaco, C. D., \& Epstein, L. (2003). The Complete Idiot's Guide to the Politics of Oil.

https://books.google.com.hk/books?id=HXTHdgJUZ5oC\&dq=Iraq+war+rebuild+Iraq +US+interest\&hl=zh-TW\&source=gbs_navlinks_S

Newton, M. A., \& May, L. (2014). Proportionality in International Law. https://books.google.com.hk/books?id=oekkAwAAQBAJ\&dq=just+war+jus+in+bello+ proportionality+of+weapons+usage\&hl=zh-TW\&source=gbs_navlinks_s

Ohaegbulam, F. U. (2007). A Culture of Deference: Congress, the President, and the Course of the U.S. - Led Invasion and Occupation of Iraq. https://books.google.fr/books?id=R0EtC4ox0ZMC\&dq=Iraq-Kuwait+dispute+territor $\mathrm{y}+$ oil\&source $=\mathrm{gbs} \_$navlinks_s

Orend, B. (2007). Jus Post Bellum: The Perspective of a Just-War Theorist. Leiden Journal of International Law, 20, 571-591. https://doi.org/10.1017/S0922156507004268 https://www.cambridge.org/core/services/aop-cambridge-core/content/view/S0922156 $\underline{507004268}$

Parry, J. (2015). Just War Theory, Legitimate Authority, and Irregular Belligerency. Philosophia, 43, 175-196. https://link.springer.com/article/10.1007\%2Fs11406-014-9577-z https://doi.org/10.1007/s11406-014-9577-z

Pugliese, J. (2013). State Violence and the Execution of Law: Biopolitical Caesurae of Torture, Black Sites, Drones.

https://books.google.com.hk/books?id=WXK1_vylBVMC\&pg=PA51\&dq=iraq+war+fou $\underline{\text { rteen }+ \text { civilians+were+killed\&hl=zh-TW\&sa }=\text { X\&ved=0ahUKEwjf-M2TnuDaAhWBFpQ }}$ KHckkDcoQ6AEIJjAA

Rae, S. B. (2009). Moral Choices: An Introduction to Ethics. https://books.google.com.hk/books?id=5llPjOOggrgC\&dq=pacifism+Iraq+War+unjust +war\&hl=zh-TW\&source=gbs_navlinks_s

Saad, L. (2002). Top Ten Findings about Public Opinion and Iraq Public Still Supportive of Iraq Invasion, but with Reservations. https://news.gallup.com/poll/6964/top-ten-findings-about-public-opinion-iraq.aspx

Security Council (2003). United Nations Weapons Inspectors Report to Security Council on Progress in Disarmament of Iraq. https://www.un.org/press/en/2003/sc7682.doc.htm

Solis, G. D. (2010). The Law of Armed Conflict: International Humanitarian Law in War. https://books.google.com.hk/books?id=6FKf0ocxEPAC\&dq=Proportionality+jus+ad+ bellum\&hl=zh-TW\&source $=$ gbs_navlinks_s

Steed, B. L. (2019). Iraq War: The Essential Reference Guide. https://books.google.fr/books?id=PXmFDwAAQBAJ\&dq=iraq+war+end+in+2011\&so urce=gbs_navlinks_s 
The British Government (2002). Iraq's Weapons of Mass Destruction (776073).

http://news.bbc.co.uk/nol/shared/spl/hi/middle_east/02/uk_dossier_on_iraq/pdf/iraqd ossier.pdf

The New York Times (2002). Text: Bush's Speech to U.N. on Iraq. https://www.nytimes.com/2002/09/12/politics/text-bushs-speech-to-un-on-iraq.html

The Sydney Morning Herald (2010). WikiLeaks Reveals War "Bloodbath". https://www.smh.com.au/world/wikileaks-reveals-war-bloodbath-20101023-16yk0.html

The U.S. Department of Defense (2019). Operation Iraqi Freedom U.S. Casualty Status. https://dod.defense.gov/News/Casualty-Status

The Washington Post (2002). Text of President Bush's 2002 State of the Union Address. https://www.washingtonpost.com/wp-srv/onpolitics/transcripts/sou012902.htm

Trotta, D. (2013). Iraq War Costs U.S. More than \$2 Trillion: Study. Reuters. https://www.reuters.com/article/us-iraq-war-anniversary-idUSBRE92D0PG20130314

Walzer, M. (2015). Just and Unjust Wars: A Moral Argument with Historical Illustrations.

https://books.google.com.hk/books?id=EuTQCQAAQBAJ\&dq=Just+and+Unjust+War s\&hl=zh-TW\&source=gbs_navlinks_s

Webel, C. P., \& Barash, D. P. (2013). Peace and Conflict Studies. https://books.google.com.hk/books?id=cbRuof3KLLgC\&dq=Proportionality+of +good +bad+outcome+jus+ad+bellum+just+war+theory\&hl=zh-TW\&source=gbs_navlinks_s

Welch, D. (2013). Propaganda, Power and Persuasion: From World War I to Wikileaks. https://books.google.com.hk/books?id=CpDPBAAAQBAJ\&dq=2003+Iraq+war+politic $\underline{\mathrm{al}+\text { realism }+ \text { protect+national+interest\&hl=zh-TW\&source }=\mathrm{gbs} \_ \text {navlinks_s }}$

Williams, P. D. (2012). Security Studies: An Introduction. https://books.google.com.hk/books?id=isnfBQAAQBAJ\&dq=Iraq+war+political+realis $\underline{\mathrm{m}+\text { protect}+ \text { national }+ \text { interest } \& \mathrm{hl}=\mathrm{zh}-\mathrm{TW} \& \text { source }=\mathrm{gbs} \_ \text {navlinks_s }}$ 